\title{
Errata
}

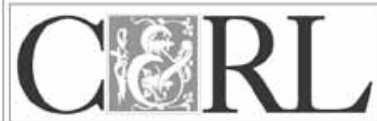

In the September 2010 article "Seeking Full Citizenship: A Defense of Tenure Faculty Status for Librarians" by Coker, vanDuinkerken, and Bale, note 67 appears as follows:

67. Gail R. Gilbert, "Keeping the Bar High: The Reinstatement of Tenure for Librarians at the University of Louisville," Kentucky Libraries 71, no. 2, 1961: 17-19.

Gilbert's article was published in the Spring 2007 issue of Kentucky Libraries, not 1961.

We regret the error.

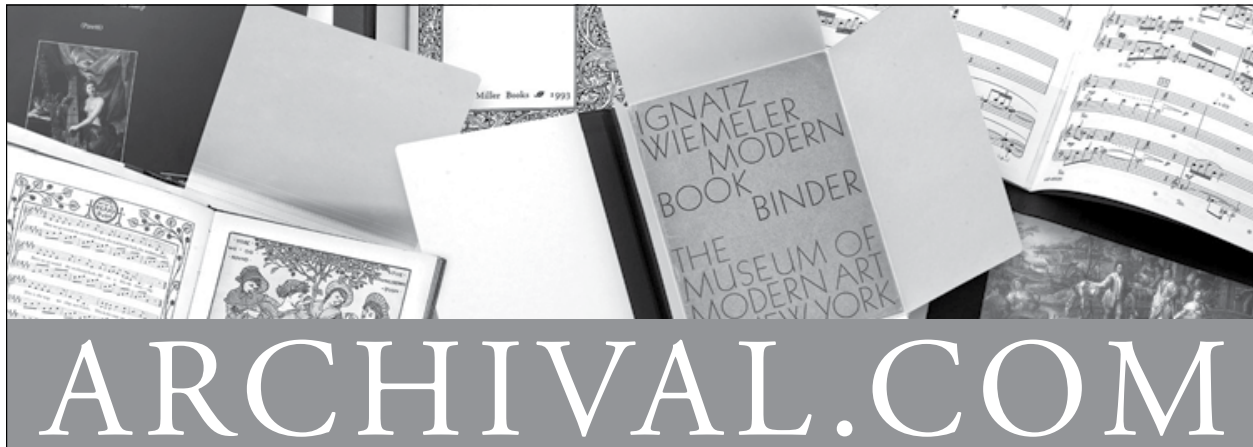

INNOVATIVE SOLUTIONS FOR PRESERVATION

Call for a complete catalog

Pamphlet Binders Music Binders Archival Folders Manuscript Folders Hinge Board Covers Academy Folders Newspaper/Map Folders Bound Four Flap Enclosures Archival Binders
Polypropylene Sheet \& Photo Protectors Archival Boards Adhesives

Bookkeeper Century Boxes Conservation Cloths Non-Glare Polypropylene Book Covers CoLibri Book Cover System

\section{ARCHIVAL PRODUCTS}

P.O. Box 1413

Des Moines, Iowa 50306-1413

Phone: 800.526.5640

Fax: 888.220.2397

E-mail: custserv@archival.com Web: archival.com 